\title{
EVALUATION OF THE USLE MODEL TO ESTIMATE WATER EROSION IN AN ALFISOL
}

\author{
B. Olivares ${ }^{1}$, K. Verbist ${ }^{2}$, D. Lobo ${ }^{3}$, R. Vargas $^{4}$ and O. Silva ${ }^{5}$ \\ ${ }^{1}$ Instituto Nacional de Investigaciones Agrícolas (INIA), carretera vía Soledad, El Tigre estado \\ Anzoátegui, Venezuela. ${ }^{2}$ Department of Soil Management, Ghent University and Centro del Agua \\ para las Zonas Áridas y Semiáridas de América Latina y el Caribe, La Serena, Chile \\ (CAZALAC). ${ }^{3}$ Departamento de Edafología, Facultad de Agronomía, Universidad Central de \\ Venezuela, Maracay, estado Aragua. ${ }^{4}$ Corporación Nacional Forestal, Región Metropolitana, \\ Santiago, Chile. ${ }^{5}$ Departamento de Agronomía, Facultad de Agronomía, Universidad Central de \\ Venezuela, Maracay, estado Aragua.*Corresponding author: barlinolivares@gmail.com
}

\begin{abstract}
The USLE model was evaluated to estimate water erosion in an Alfisol located in San Pedro, Metropolitan Region of Chile. Values of erosivity (R) obtained by using the Arnoldus approximation (MFI) and equations proposed by the Institute for Nature Conservation (ICONA) in Spain were adapted to the conditions in Chile. For the evaluation of soil loss, data were used for each precipitation event causing erosion during the period 1996-2000, obtained by measurements on experimental plots with treatments of subsoiling, infiltration trenches and natural prairie. They were compared with estimated values of erosion in terms of basic statistics and indices based on variance and regression. In the descriptive and comparative analysis of the selected equations, it was determined that soil losses estimated with USLE using the equation of rainfall erosivity by ICONA provided soil loss values which were well-adjusted to the values recorded in Chile, compared to erosivity calculated by the Arnoldus approximation (MFI) that overestimated the soil loss values. According to the results or estimates in this study it was concluded that the USLE model was capable of detecting the trend of the data, and resulted in estimates consistent with the pattern observed in the field data.
\end{abstract}

Keywords: Soil erosion, erosivity, USLE.

\section{INTRODUCTION}

In Chile, the erosion hazard is considered one of the most important degradation processes leading to significant loss of land productive capacity (Nachtergaele $e t$ al., 2010; Soto, 1999). It is precisely for this reason that there is a need to assess water erosion in terms of soil loss under different management practices, thus applying measures to prevent mayor soil losses.
The soil is the main productive resource that agricultural producers and foresters have at their disposal and its degradation involves a huge disadvantage in the current model of economic development (Santibáñez et al., 1998), characterized by strong competition between producers, countries and even groups of countries. Because of this, the government of Chile has established programs aimed at 
slowing or reversing the processes of degradation, allowing producers to access state resources to be devoted to promoting conservation, sustainable management and recovery of soils for agricultural use (Mancilla, 2006). This study provides a theoretical base and experimental practice to select adequate soil conservation strategies.

Different approaches have been developed. Qualitative models such as those proposed by Honorato et al. (2001) include the mapping of homogeneous units in terms of the main parameters that control the erosion. Quantitative models allow the numerical estimation of erosion and may include direct or indirect assessment. Direct assessment is carried out on field plots for erosion measurement or by measuring variables such as sediment in runoff water and from rainfall simulators (Verbist et al., 2003), whose data are extrapolated to homogeneous areas. Indirect assessment methods are related to models which are simplified representations of reality, and within this group statistical models, physical models and parametric models can be distinguished.

The universal soil loss equation (USLE) was designed to make annual estimates of soil loss (Renard et al., 1996). In this sense, the USLE model is used to estimate values at longer time scales than those obtained from field observations (Biesemans et al., 2000), since the model is able to establish trends. Differences between model predictions and field measurements can be often attributed to low soil loss values, and thus relative higher measurement errrs, but are also due to the use of monthly rainfall erosivity equations for rainfall (R) that can hide the erosive effect of highintensity daily rainfall. Another source of possible differences can also be attributed to the fact that the USLE soil erodibility factor $\mathrm{K}$ does not consider soil moisture, although the antecedent moisture has a significant effect on erosion. Similarly, the $\mathrm{K}$ factor does not reflect the shortterm changes produced in soil physical characteristics, especially in disturbed sites. In addition, it has been shown that the presence of rock fragments on the surface of the soil reduces erosion rates and runoff (Oyarzún, 1993). All these aspects can lead to significant differences between erosion rates and estimates with the USLE. Basically, the choice of model (USLE) in this research is due to the fact that the empirical model is most widely used and relatively simple to assess soil loss by sheet and furrow erosion, and includes the influence of precipitation, soil texture, topography, soil cover or land use and conservation practices on soil loss estimates.

Erosion modeling studies using field plots for calibration are not very abundant in Chile, due to high field installation and maintenance costs. Honorato et al., (2001) did evaluate soil losses in 42 agroecological situations in 6 locations between the $\mathrm{IV}^{\text {th }}$ and $\mathrm{IX}^{\text {th }}$ Region of Chile, with a precipitation range from 100 to $1800 \mathrm{~mm}$. When comparing the USLE model with observations, the model had good predictive performance in areas with significant erosion (> $2.5 \mathrm{Mg}$. $\mathrm{ha}^{-1} \mathrm{yr}^{-1}$ ) and management practices that favored erosion such as bare soil and tillage. However, the model underestimated the observed soil loss by $50 \%$, mainly due to $\mathrm{R}$ factor estimated by approximating Arnoldus (MFI) (1980), whose values did not provide sufficient accuracy to represent the rainfall erosivity, as well as due to the $C$ factor whose values were not properly quantified in relation to the assigned management practices.

Millas (1977) estimated a soil loss of 8.8 and $9.9 \mathrm{Mg} \mathrm{ha}^{-1} \mathrm{yr}^{-1}$ in two granitic soils of the Cauquenes series (with a crop rotation of potato, wheat, barley and fallow) using USLE, while Riquelme 
(1994) calculated a value of $8.8 \mathrm{Mg}$ $\mathrm{h}^{-1} \mathrm{yr}^{-1}$ for a monoculture of wheat and conventional tillage and the same soil.

The present work aims at studying the goodness of fit in estimating water erosion by the USLE model on an Alfisol under different soil management in the Metropolitan Region of Chile, specifically in a watershed located in the Village of San Pedro, comparing soil loss estimates provided by the model with the respective erosion measurements obtained at experimental plots with three different treatments for different years. Special attention was given to the estimation of the $\mathrm{R}$ factor for this area, which was found to be a source of model error previously.

\section{Description of the study area}

The experimental plots were located in the town of Alto Loica, Commune of San Pedro, Melipilla Province in the Metropolitan Region of Chile (Figure 2), and is located on the eastern slopes of the Cordillera de la Costa, $120 \mathrm{~km}$ southwest of Santiago de Chile; at $-34^{\circ} 01^{\prime} 58.8^{\prime \prime}$ Latitude and $-71^{\circ} 25^{\prime} 1.2^{\prime \prime} \quad$ Longitude (Tokugawa and Vargas, 1996).

The type of soil where the measurements were located corresponds to an Alfisol belonging to the Cauquenes Series. The representative pedon of the Cauquenes association is a member of the Ultic Paleoxeralfs; fine, kaolinitic, isomesic, according to the soil classification system of the USDA (1993). These are deep soils formed in situ from granitic rocks, and evolved to yellowish reddish brown 5 YR hue on the surface and deep yellow hue in the same above. It rests on a substrate consisting of highly weathered granite and occupies a topographic position on hills and hillocks. It features brick structure in the first two horizons, both glass and granite gravel on the surface. Located in highly undulating slopes with 15 to $20 \%$, they are characterized by severe erosion and are mostly well drained. Regarding usability of the soil, it was classified as Class VII (of 8), which means low soil quality, and was attached the letter (e), which means limited erosion (Martínez, 2004).

Alto Loica (San Pedro) has a temperate, Mediterranean climate characterized by a dry summer season (December to March). Average annual rainfall is $399 \mathrm{~mm}$ and tends to increase eastward toward the Andes, because orographic effects, and from north to south, due to an increased influence of the midlatitude storm track. The temperature range is very low with an annual average of $14^{\circ} \mathrm{C}$, a maximum of $28^{\circ} \mathrm{C}$ in the summer period, and winter minimum temperatures of 5 to $6^{\circ} \mathrm{C}$ (Tokugawa and Vargas, 1996).

The typical vegetation of the area consists of Espino (Acacia dig) Quillay (Quillaja saponaria), Boldo (Peumus boldus) and Maite (Maytenus boaria), Romerillo (Lomatia ferrugenea), Trevo (Dasyphyllum diacanthoides) and Huañil (Proustia cuneifolia) and are characterized by low heights. The understory vegetation is dominated by grasses.

\section{Evaluation of soil loss}

The treatments evaluated in this study were developed under the project: "Erosion control and reforestation in watersheds of the semiarid zone of Chile”, which was cooperation between the National Forestry Corporation (CONAF) and the International Cooperation Agency (JICA) from 19932000. The purpose of the CONAF-JICA project was the development and application of techniques of tree nursery, forestation and soil and water conservation, to recover land that was degraded by water erosion. In this project 


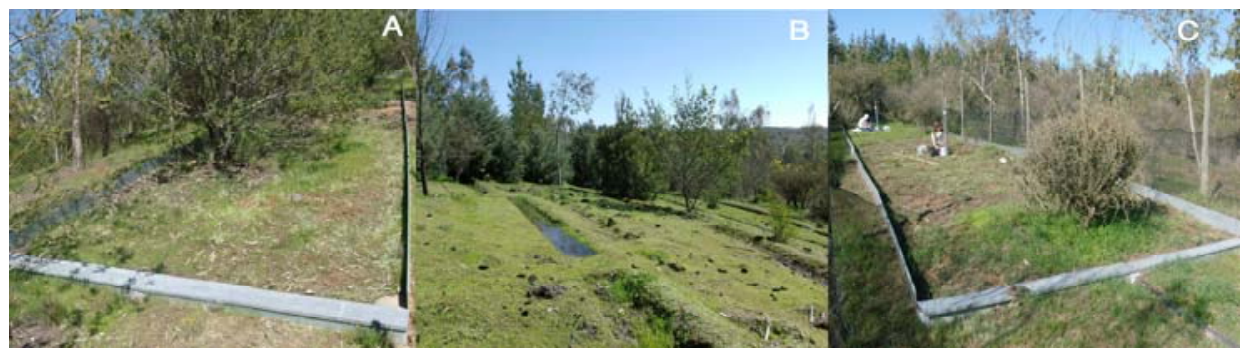

Figure 1. Photo of the different treatments, with a) subsoiling, b) infiltration trenches and c) natural prairie.

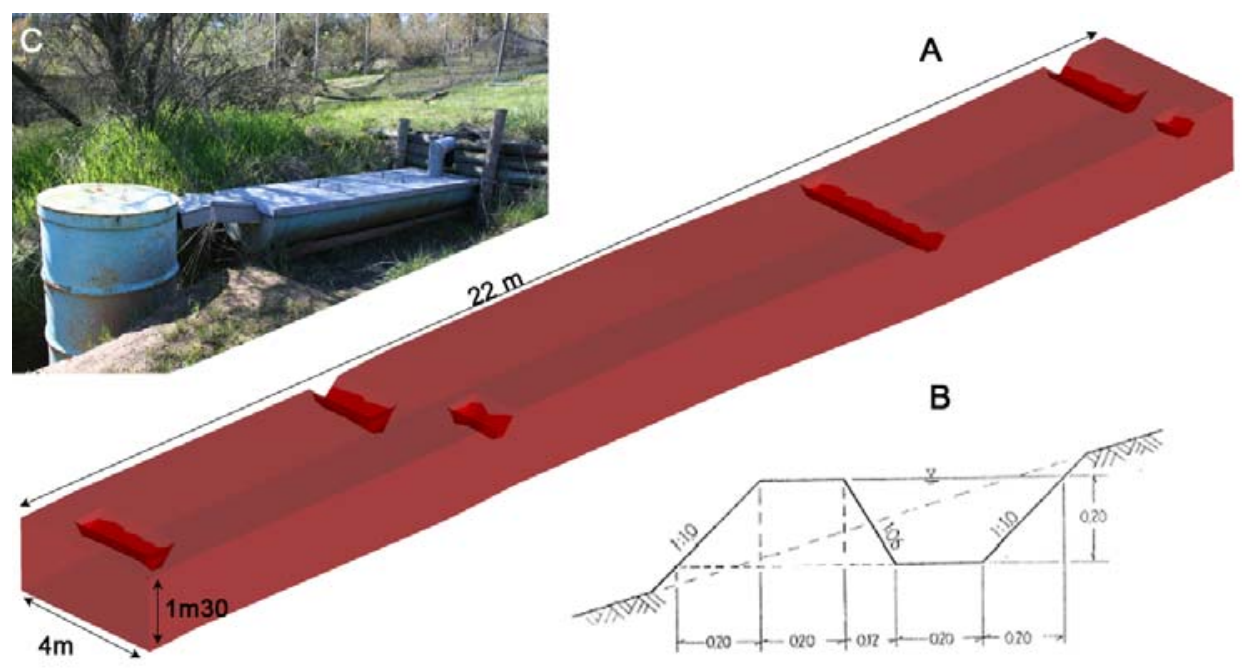

Figure 2. (a) Layout of the infiltration trenches on the Wishmeier plot, (b) trench dimensions and (c) collector drums at the plot outlet.

techniques for recovery of degraded soils were installed and soil loss measured to evaluate the effectiveness of the different techniques (Tokugawa and Vargas, 1996).

For the evaluation of soil loss, data were obtained for each rainfall event during the period 1996-2000, obtained by measuring total sediment loss (g) and total runoff amount (l) on experimental plots with treatments of subsoiling, infiltration trenches and a control treatment with natural prairie (Figure 1). Each treatment was $4 \mathrm{~m}$ wide and $22.14 \mathrm{~m}$ long (the dimensions of a typical Wischmeier plot), with a total area of $88.56 \mathrm{~m}^{2}$, bounded on its perimeter with metal sheets. In the lower base of the plots, the catchment area was equipped with a collection channel that extends across the width of the plot where the flow converges to two large metal drums (200 l each) for runoff and sediment collection (see also Figure 2c). The characteristics of each of the treatments are given in the subsequent sections. 


\section{Subsoiling treatment}

Subsoiling was applied one month before the forestation (i.e. April 1995) using a caterpillar tractor of $120 \mathrm{HP}$ equipped with a single spear (ripper) under dry soil conditions. Subsoiling to a depth of $0.5 \mathrm{~m}$ was performed perpendicular to the slope by following slope contours with the aim of improving root growth and infiltration of rainwater. The field plot has a slope of $5.7 \%$ and the vegetation is represented by Acacia species (Figure 1a).

\section{Treatment of infiltration trenches}

The infiltration trenches in this treatment were also established in 1995 (Figure 1b), and consisted of 6 trenches with variable lengths (0.6 to $3.9 \mathrm{~m})$, arranged in a near checkerboard pattern (Figure 2a). They were designed to have a rectangular section of $0.2 \mathrm{~m}$ in height, $0.2 \mathrm{~m}$ base and a top width of $0.52 \mathrm{~m}$, as shown in Figure 2b. The design also considers a lower slope angle at the upstream edge of the trench to facilitate entry of water and avoid erosion of the walls (Pizarro et al., 2005).

The treatment of infiltration trenches is located on a slope of $9.2 \%$ and vegetation cover is represented by species of Pinus radiata (Figure 1c). At this point it is appropriate to note that for reasons of methodology to characterize the USLE, the average length of the catchment area on the slope (5 m) was taken.

\section{Natural prairie treatment}

Finally, a control treatment or natural prairie was evaluated, where no technique or practice of conservation was applied (Figure 1c). It had a slope of $10.2 \%$, slightly higher than the other treatments and the plant cover in the treatment is represented by native grasses (Bromus sp.), characteristic of the study area.
Although the values obtained from the erosion plots represent only the same plots, and are not transferable to other areas with differing conditions (soil, management, use, slope), these plots are one of the few possibilities to look directly at soil losses related to management practices often applied in drylands of Chile, and can be used for the application and validation of erosion models.

\section{Estimating water erosion by USLE}

The USLE is the most widespread model for estimating erosion plots and includes the action of precipitation, soils, topography, cover and conservation practices, as indicated in Eq. 1:

$$
A=R^{*} K^{*} L * S * C * P
$$

where:

- A: soil loss expressed in the international metric system in $\mathrm{Mg} \mathrm{ha}^{-1} \mathrm{yr}^{-1}$.

- R: erosivity of rain (MJ mm ha- $\mathrm{h}^{-1}$ ).

- K: soil erodibility [( $\left.\mathrm{Mg} \mathrm{ha}^{-1}\right)$.(MJ mm ha $\left.\left.{ }^{1} \mathrm{~h}^{-1}\right)^{-1}\right]$

- L: length factor (dimensionless), soil loss influenced by the length of the slope.

- S: slope factor (dimensionless), soil loss influenced by the gradient of the slope.

- C: crop factor (dimensionless), soil loss influenced by land use.

- P: management factor (dimensionless), soil loss influenced by the use of conservation practices.

\section{Obtaining parameters of the USLE}

\section{$\underline{\text { Rainfall erosivity factor (R) }}$}

Two different methods were used to estimate annual values of water erosion: a) using the Arnoldus (1980) approximation, called Modified Fournier Index or MFI and b) by using the equation 
proposed by Valenzuela and Morales (2004) or ICONA.

The first option to estimate the rainfall erosivity from monthly data is through Eq. 2, where the rainfall erosivity $\mathrm{R}$ (MJ $\mathrm{mm} \mathrm{h} \mathrm{h}^{-1} \mathrm{~h}^{-1}$ ) is obtained by regression onto the MFI, as suggested by ICONA (1988) and adapted to the Region of Coquimbo in Chile by Valenzuela and Morales (2004) and Vandekerckhove (2006), resulting in a slope factor of $1.6881 \mathrm{~mm}^{-1}$ :

$$
R=1.6881 \sum_{i=1}^{12} \frac{P_{i}^{2}}{P_{t}}=1.6881 \mathrm{MFI}
$$

where $\mathrm{P}_{\mathrm{i}}$ represents the monthly precipitation and $\mathrm{P}_{\mathrm{t}}$ the total annual precipitation (mm).

A second procedure was developed by the Institute for the Conservation of Nature (ICONA, 1988). It should be indicated that it originated in Spain, specifically in arid and semiarid Mediterranean climate of Andalucía and Almeria and therefore reflects a specific pattern of local weather rain. The erosivity index for these areas was calculated from monthly rainfall data provided by the National Institute of Meteorology and by applying the equations proposed by ICONA (1988) for Spain, modified to local conditions of each zone that country. This modification was made considering nine parameters from which it was possible to create zones for the entire country.

Researchers in Chile (Morales and Valenzuela, 2004; Vandekerckhove, 2006) have calibrated this approach for the Coquimbo Region taking the type of climate and rainfall amounts received in the area into account, resulting in the second option to estimate the erosivity factor based on monthly precipitation data for the period $1996-2000$ :

$$
R=0,291 \cdot[P M E X]^{1,297}[M R]^{-0,511}[M V]^{0,366}[F 24]^{0,414}
$$

where $\mathrm{R}$ is the rainfall erosivity factor (hJ.cm. $\mathrm{m}^{-2} \cdot \mathrm{h}^{-1}$ ), PMEX the average monthly maximum of each year of the series (mm), MR is the average rainfall from October to May (mm),
$\mathrm{MV}$ is the average rainfall in the wet season from June to September (mm) and F24 is the concentration factor of the maximum daily rainfall, defined as:

$$
\mathrm{F} 24=\frac{(\text { maximum24h rainfallin a year })^{2}}{\sum \text { maximum24hourrainfallof allmonthsin a year }}
$$

\section{Soil erodibility factor (K)}

The estimation of the soil erodibility factor (K) was done by using the nomogram proposed by Wischmeier, and Smith (1978), according to the characteristics (\% silt + very fine sand) (\% sand too coarse to fine), organic matter (\%), permeability and soil structure, as modified by Morgan (1997) in terms of international units.

To determine the textural characteristics, the particle size distribution was determined by the hydrometer method (Gee and Or, 2002). The different sand fractions at sizes of $0.1,0.25,0.5,1$ and $2 \mathrm{~mm}$ were obtained with three samples of dry soil from each 
of the field plots (subsoil, trenches and grass), whereas the silt and clay fractions were separated by sedimentation.

The organic matter content was determined with the Walkley and Black method modified by Heanes (1984). Soil structure, obtained through field measurements, was classified according to USDA (1993) and was found to be blocky at all sites.

Finally, the permeability was determined with the tension infiltrometer (Clothier and White, 1981), resulting in a similar and slow permeability according to Porta et al. (1999) on all plots.

\section{Topographic factors (LS)}

The S factors were determined from Eq. 5 (Wischmeier and Smith, 1978) for each of the treatments:

$$
S=0,065+0,045 s+0,0065 s^{2}
$$

where s is the slope (\%).

To determine the length of the slope factor in the plot with infiltration trenches Eq. 6 was used:

$$
L=(l / 22,1)^{\mu}
$$

where $l$ is the length of the runoff on the slope, and $\mu$ a gradient-dependent factor, which is calculated by Eq. 7 (Wischmeier and Smith, 1978).

$$
\mu=0,6 *\left[1-e^{(-35,835 . S)}\right][7]
$$

Factor use and land management (C) and conservation practice $(\mathrm{P})$

Factor $\mathrm{C}$ was set as a linear function in time to Acacia plantations and Pinus radiata located in the subsoil treatment and infiltration trenches, respectively, since the cover of both plantations varied considerably over time. In this factor, the following three sub-factors were considered: (i) the canopy cover subfactor and single story (Wischmeier and Smith, 1978), (ii) the reconsolidation of the soil, associated with soil disturbance by tillage (Wischmeyer and Foster, 1980) and (iii) the fine roots in the surface layer (Wischmeyer and Foster, 1980). In the case of the natural pasture treatment, the value $\mathrm{C}$ is considered stable since it was assumed that no significant changes in land cover occurred over time.

Moreover, with respect to the contour tillage factor ( $\mathrm{P}$ factor) the subsoiling treatment was assigned a value of 0.5 as proposed by Wischmeier and Smith (1978) according to the gradient of the slope.

Comparison of actual and simulated erosion

The measured soil loss values at the erosion plots located in the study area with different land use types and conservation practices were compared with values estimated by the USLE erosion, applying two versions of $\mathrm{R}$ factor calculations: a) estimated by Arnoldus approximation using MFI (1980) and b) estimated from the ICONA equation (1988).

The comparison between estimated and measured values was performed by comparing the average, standard deviation, skewness and kurtosis, statistics based on differences such as simulation efficiency (EF) (Greenwood et al., 1985), the coefficient of agreement (d) (Willmott and Wicks, 1980), the mean absolute error (MAE) (Shaeffer, 1980) and finally the regression-based statistics; the Pearson correlation coefficient and slope, intercept and the probability that the slope and intercept are one and zero. 


\section{RESULTS}

\section{Measured soil loss}

Table 1 shows the values of soil loss and the respective amounts of total precipitation for the period of evaluation, clearly highlighting the erratic annual rainfall, showing above normal rainfall conditions during the years 1997 and 2000, with 1034.5 and $866 \mathrm{~mm}$ respectively, while the average for the study area is $399 \mathrm{~mm}$. In contrast, very little precipitation was observed in 1998 $(141.5 \mathrm{~mm})$. This shows that rainfall is highly influenced by the direct influence of El Niño in the years of highest rainfall total, as already documented for the IV Region of Coquimbo by Verbist et al. (2010). The remaining years 1996 and 1999 had more normal rainfall seasons, with rainfall amounts of 314.4 and 487.5 $\mathrm{mm}$ respectively.

It is emphasized that the highest soil loss was generated in the years with highest annual precipitation. This confirms that observed soil losses are closely related to rainfall, in part by the power of detachment by rain drops impacting the soil and partly due to the scouring effect by runoff on sediment detachment and transport (Wischmeier and Smith, 1978).

The values of the standard deviation and coefficient of variation for all treatments are considered high, more than $50 \%$ for the latter, confirming the high interannual variability of the data series.

\section{Comparison of measured and estimated soil loss}

\section{Evaluation of the treatments individually}

Differences were observed between the soil loss observed in the subsoiling treatment and the modeled values using
USLE, with both approximations of the $\mathrm{R}$ factor, as observed in Table 1. For the period 1996-1998 both modeled soil losses overestimate the measured value, while the USLE version using R (MFI) resulted in the largest values. For the last two years (1999-2000), both model versions subestimated soil losses, with $\mathrm{R}$ (ICONA) showing the lowest values. Nevertheless, the same trend was observed with both the model versions and the measurements, showing a similar trend.

In the Infiltration trench treatment, soil loss was overestimated with both USLE versions (Table 1), with the USLE with $\mathrm{R}$ (MFI) showing much higher values than obtained with R (ICONA). In general, however, both model versions generated a similar tendency in soil loss values as observed in the field, although the absolute values differ in some years, especially for the model version with $\mathrm{R}$ (MFI).

In the case of the natural prairie, the adaptation of the USLE model with $\mathrm{R}$ (MFI) also gave an overestimation of the soil loss since the start of the observations (Table 1), as observed in the treatment of subsoiling and infiltration trenches. The USLE version with $\mathrm{R}$ (ICONA) on the other hand, gave values with little variation in time that were close to those observed at that treatment.

\section{Evaluation of the treatments together}

Comparing the measured erosion values in all treatments with their simulated values, shown in Table 2, both USLE versions with different $R$ values overestimated soil erosion. The USLE with the ICONA $\mathrm{R}$ value presented total and average values closest to those measured, whereas the $\mathrm{R}$ estimated from MFI showed a clear overestimation, with significant bias, increased skewness and kurtosis. 
J. Soil Sci. Plant Nutr. 11 (2): $71-84$ (2011)

Table 1. Precipitation, USLE subfactors and modelled soil loss, as well as field measured soil loss values for the three treatments.

\begin{tabular}{|c|c|c|c|c|c|c|c|c|c|c|c|}
\hline \multirow{2}{*}{ Year } & \multirow{2}{*}{ Precipitation } & \multicolumn{2}{|c|}{$\mathbf{R}$} & \multirow{2}{*}{$\mathbf{K}$} & \multirow{2}{*}{$\mathbf{L}$} & \multirow{2}{*}{$\mathbf{S}$} & \multirow{2}{*}{$\mathrm{C}$} & \multirow{2}{*}{$\mathbf{P}$} & \multicolumn{3}{|c|}{ A $\left(\mathrm{Mg} \mathrm{ha}^{-1}\right)$} \\
\hline & & MFI & ICONA & & & & & & MFI & ICONA & Measured \\
\hline \multicolumn{12}{|c|}{ Subsoiling } \\
\hline 1996 & 314.4 & 132.97 & 101.97 & 0.03 & 1 & 0.532 & 0.172 & 0.5 & 0.183 & 0.140 & 0.097 \\
\hline 1997 & 1034.5 & 378.37 & 170.40 & 0.03 & 1 & 0.532 & 0.138 & 0.5 & 0.417 & 0.188 & 0.151 \\
\hline 1998 & 141.5 & 66.65 & 34.11 & 0.03 & 1 & 0.532 & 0.104 & 0.5 & 0.055 & 0.028 & 0.026 \\
\hline 1999 & 487.5 & 177.64 & 154.20 & 0.03 & 1 & 0.532 & 0.071 & 0.5 & 0.101 & 0.087 & 0.278 \\
\hline 2000 & 866.0 & 782.75 & 672.40 & 0.03 & 1 & 0.532 & 0.037 & 0.5 & 0.231 & 0.199 & 0.276 \\
\hline \multicolumn{12}{|c|}{ Infiltration trenches } \\
\hline 1996 & 314.4 & 132.97 & 101.97 & 0.03 & 0.475 & 1 & 0.148 & - & 0.280 & 0.215 & 0.051 \\
\hline 1997 & 1034.5 & 378.37 & 170.40 & 0.03 & 0.475 & 1 & 0.118 & - & 0.636 & 0.287 & 0.163 \\
\hline 1998 & 141.5 & 66.65 & 34.11 & 0.03 & 0.475 & 1 & 0.088 & - & 0.084 & 0.043 & 0.042 \\
\hline 1999 & 487.5 & 177.64 & 154.20 & 0.03 & 0.475 & 1 & 0.058 & - & 0.147 & 0.127 & 0.083 \\
\hline 2000 & 866.0 & 782.75 & 672.40 & 0.03 & 0.475 & 1 & 0.028 & - & 0.312 & 0.268 & 0.115 \\
\hline \multicolumn{12}{|c|}{ Natural prairie } \\
\hline 1996 & 314.4 & 132.97 & 101.97 & 0.04 & 1 & 1.2 & 0.005 & - & 0.032 & 0.024 & 0.020 \\
\hline 1997 & 1034.5 & 378.37 & 170.40 & 0.04 & 1 & 1.2 & 0.005 & - & 0.091 & 0.041 & 0.036 \\
\hline 1998 & 141.5 & 66.65 & 34.11 & 0.04 & 1 & 1.2 & 0.005 & - & 0.016 & 0.008 & 0.030 \\
\hline 1999 & 487.5 & 177.64 & 154.20 & 0.04 & 1 & 1.2 & 0.005 & - & 0.043 & 0.037 & 0.068 \\
\hline 2000 & 866.0 & 782.75 & 672.40 & 0.04 & 1 & 1.2 & 0.005 & - & 0.188 & 0.161 & 0.072 \\
\hline
\end{tabular}


Table 2. Basic statistics of measured and simulated erosion for all treatments $(n=15)$.

\begin{tabular}{lccc}
\hline \multirow{2}{*}{ Basic statistics } & & \multicolumn{2}{c}{ USLE-calculated } \\
& Measured & R (MFI) & R (ICONA) \\
\hline Sum $\left(\mathrm{Mg} \mathrm{ha}^{-1}\right)$ & 1.50 & 2.81 & 1.85 \\
Average $\left(\mathrm{Mg} \mathrm{ha}^{-1}\right)$ & 0.10 & 0.18 & 0.12 \\
Standard deviation $\left(\mathrm{Mg} \mathrm{ha}^{-1}\right)$ & 0.08 & 0.16 & 0.09 \\
Skewness & 1.31 & 1.49 & 0.37 \\
Kurtosis & 0.90 & 2.38 & -1.19 \\
\hline
\end{tabular}

\section{Evaluation of different simulations}

The simulation efficiency is shown in Table 3, resulting in negative values for both versions of the USLE model, which means that the generated error magnitudes suggest that the average of the measured values would be a better estimate than the simulated results obtained. According to the index values match, the option of USLE which generated a higher value was R (ICONA), which is interpreted as greater consistency between the values of measured and simulated erosion. The average absolute error was higher for the option of USLE with R (MFI), i.e. a greater average difference between measured and estimated values. In general, both absolute mean error values are considered high since they are higher than half the standard deviation of the measured values.

\section{Evaluation of correlation and trend}

As shown in Table 4, the regression coefficient was higher for the USLE option with R (ICONA), but both values gave low or weak correlations between the measured and simulated erosion. Evaluating the joint probability that the intercept is zero and slope one, indicated that for both model versions this probability is very similar. However, studying the separate probabilities, it is noted that the intercept has a greater probability of being zero in the USLE version with $\mathrm{R}$ (MFI), likewise for the probability that the slope is one.

Table 3. Statistics based on difference of measured and estimated erosion for all treatments.

\begin{tabular}{lcc}
\hline \multirow{2}{*}{ Index } & \multicolumn{3}{c}{ USLE using } \\
& R (MFI) & R (ICONA) \\
\hline Simulation efficiency (EF) & -3.60 & -0.25 \\
Concordance index (d) & 0.45 & 0.67 \\
Mean Absolute Error (MAE) & 0.12 & 0.06 \\
\hline
\end{tabular}


Table 4. Regression statistics of measured and estimated erosion for all treatments.

\begin{tabular}{lcc}
\hline \multirow{2}{*}{ Parameters } & \multicolumn{2}{c}{ USLE using } \\
& R (MFI) & R (ICONA) \\
\hline Correlation coefficient (R) & 0.40 & 0.48 \\
Intercept (b0) & 0.10 & 0.06 \\
Probability of Intercept (b0) & 0.13 & 0.06 \\
Slope (b1) & 0.82 & 0.53 \\
Probability of the slope (b1) & 0.74 & 0.11 \\
Probability b1=1; b0=0 & 0.25 & 0.21 \\
\hline
\end{tabular}

According to Figure 3, which shows measured and estimated erosion by the two versions of rainfall erosivity for each of the treatments, it is clear that most of the estimated soil loss values are above the 1:1 line. With regard to the low values of soil loss observed, these tend to be overestimated by the adaptation of USLE with R (MFI), except for two events of lower magnitude. On the other hand, the adaptation of USLE with R (ICONA) had values close to the measured values. Overall, it appears that both adaptations despite the differences in magnitude follow the same trend.

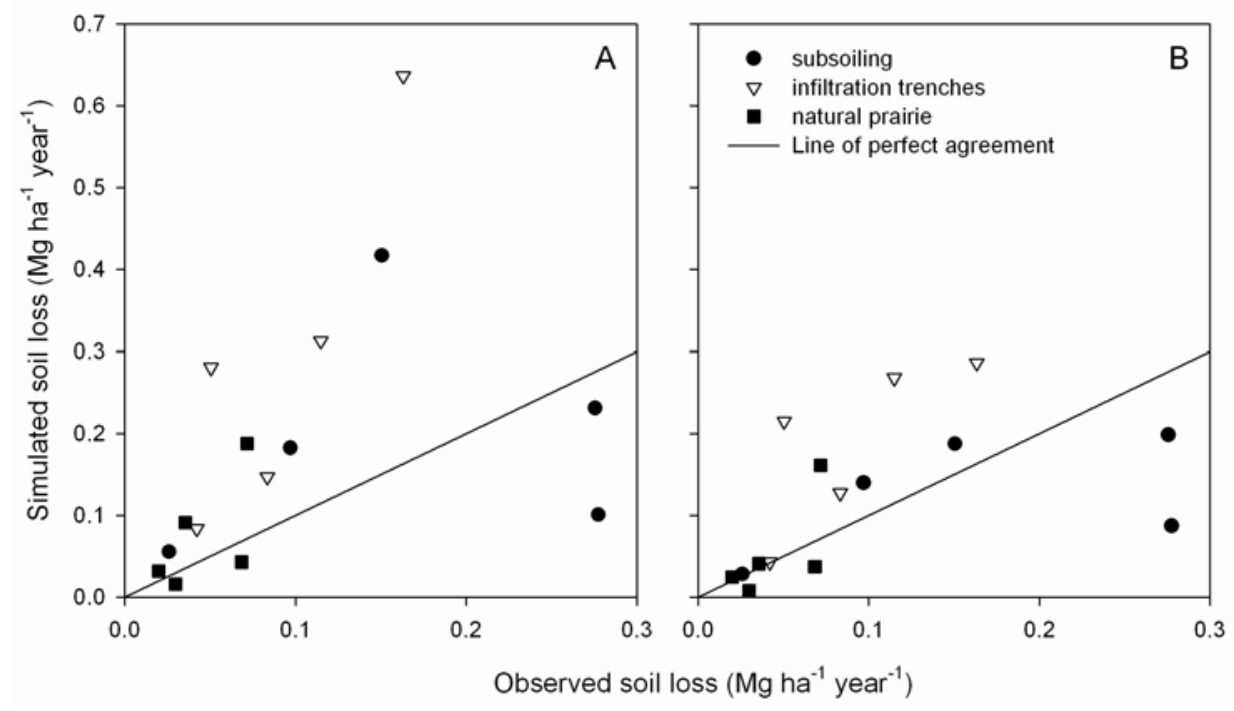

Figure 3. Measured and estimated soil erosion by USLE with (a) R (MFI) and (b) R (ICONA) for each of the treatments. The gray line indicates the line of perfect agreement. 
Overall, the statistics used to compare the soil loss values measured in the field and estimated by two USLE model options show comparable trends, indicating that the estimated values follow a similar distribution to those observed in the field.

The USLE model was evaluated by Honorato et al., (2001) at 6 locations between IV and IX Region of Chile, with a precipitation range from 100 to 1800 $\mathrm{mm}$. The model was not a good predictive performance in areas with significant erosion (> $2.5 \mathrm{Mg} \mathrm{ha}^{-1} \mathrm{yr}^{-1}$ ) with bare soil treatments such as tillage. The model did not provide good estimates of erosion, mainly due to $\mathrm{R}$ factor estimated by approximating Arnoldus (MFI) (1980), whose values did not provide sufficient accuracy to estimate rainfall erosivity.

The $\mathrm{R}$ factor from the station of Las Cardas, Chile (40.2 MJ mm ha ${ }^{-1} \mathrm{~h}^{-1} \mathrm{y}^{-1}$ ) was estimated by (Vandekerckhove, 2006) using the linear regression between MFI and R of Valenzuela and Morales (2004). Where $\mathrm{R}$ itself was already an estimation of the $\mathrm{R}$ calculated with the RUSLE method. The resulting estimated absolute values are unlikely to be very good estimates because of the following reasons: first, the lack of adequate rainfall data to calculate a good average erosivity factor R and second, RUSLE is an empirical model, designed for homogeneous agricultural fields in North America. The lack of data to calibrate and validate the RUSLE model makes it difficult to assess the validity of the RUSLE model.

Because of the high variability of the rainfall, an event based model would probably yield better estimates, but then, accurate data of each used rainfall event would be needed, which are not always available.

\section{CONCLUSIONS}

Because of the empirical origin of the Universal Equation Soil Loss (USLE) and the procedures for calculating each of the factors, it is stressed that these are not universal, i.e. the uncertainty of its predictions is far greater than the conditions that apply to resemble the conditions that initially were obtained. For this reason, the resulting simulated values obtained in this study should be interpreted only to derive general trends. Indeed, the USLE model was able to represent the trend of the data, i.e. the estimated data were consistent and followed the same pattern of data taken in the field, despite the over-and underestimations.

Possible causes of model behavior in USLE erosion estimates for the study area are first, the low soil loss observed in the treatments of subsoiling, infiltration trenches and natural prairie, where the error can be larger than the observed value. Likewise, the use of monthly precipitation in both equations used to calculate the factor of rain erosivity, which may obscure the erosive effect of high intensity daily rainfall.

By way of recommendation it should be stressed that there is a need to include a plot of bare soil in this type of study, allowing to compare with a control situation when estimating the influences of the $\mathrm{C}$ and $\mathrm{P}$ factors on land use and land management. It would also be recommended to estimate the rainfall erosivity factor for the study area from high resolution rain gage data, which would allow a more accurately estimate for the rain erosive capacity in the area, through the calculation of the EI30 index. 


\section{ACKNOWLEDGEMENTS}

The financial support provided by the Chilean based Water Center for Arid and Semi-Latin America and the Caribbean (CAZALAC) is acknowledged for supporting the realization of this work, framed within the research conducted by the center with technical and financial support of the Flemish Government, through the IHP - UNESCO Flanders Trust Fund.

\section{REFERENCES}

Arnoldus, H.M.J. 1980. An approximation of the rainfall factor in the Universal Soil Loss Equation. In M. De Boodt and D. Gabriels. (eds.). Assessment of soil erosion. John Wiley and Sons, Chichester, Gran Bretaña. p. 127-132.

Biesemans, J., Van Meirvenne, M., Gabriels, D., 2000. Extending the RUSLE with the Monte Carlo error propagation technique to predict long term average off-site sediment accumulation. J. Soil Water Conserv., 55(1), 35-42.

Clothier, B.E., White, I., 1981. Measurement of sorptivity and soil water diffusivity in the field. Soil Sci. Soc. Am. J., 45, 241-245.

Gee, G.W., Or, D.. 2002. Particle-Size Analysis. Chapter 2.4. pp. 255-293. In: JH Dane \& GC Topp (eds). Methods of Soil Analysis. Part 4: Physical Methods. Soil Science Society of America Inc. Madison, Wisconsin, USA.

Greenwood, D., Neeteson, J., Draycott, A 1985. Response of potatoes to $\mathrm{N}$ fertilizer: dynamic model. Plant Soil, 85: 185-203.

Heanes, D. 1984. Determination of total organic $\mathrm{C}$ in Soils by animproved chromic acid digestion and spectrophotometric procedure. Comun. in Soil Sci. Plant Anal. 15 (10): 1191-1213.

Honorato, R., Barrales, L., Peña, I., Barrera, F. 2001. Evaluación del modelo USLE en la estimación de la erosión en seis localidades entre la IV y IX Región de Chile. Cien. Inv. Agr. 28(1): 7-14. [En linea], consultado el 02 de febrero de 2009. En: http://rcia.uc.cl/Espanol/pdf/28-1/714.pdf
ICONA (1988). Agresividad de la lluvia en España. Valores del factor $\mathrm{R}$ de la ecuación universal de pérdidas de suelo. Servicio de publicaciones del Ministerio de Agricultura, Pesca y Alimentación. Ed. Ariel, S.A. Barcelona, Madrid. 292 p.

Mancilla, G. 2006. El uso de modelos de erosión para la planificación de actividades forestales (parte I). Ambiente For. (Chile) 1(2): 42-45.

Martínez, R. 2004. Mapa de reconocimiento de suelos de la VIII Region del Bio-Bio (sector sur).Tesis de grado. Santiago, Chile; Universidad de Chile.147 p.

Millas, G. 1977. Determinación de pérdidas de suelo utilizando la ecuación universal de la erosion en 10 localidades del sur de Chile. Universidad de Chile. Facultad de Agronomía. 110 pp.

Morgan, R. 1997. Erosión y conservación de suelo. Madrid, España, Ediciones MundiPrensa.343p.

Nachtergaele, F.O., Petri, M., Biancalani, R., van Lynden, G., van Velthuizen, H., 2010. Global Land Degradation Information System (GLADIS). An Information database for Land Degradation Assessment at Global Level., Technical report of the LADA FAO / UNEP Project.

Oyarzún, C. 1993. Estimación de los procesos de erosión hídrica en un ambiente montañoso de la cuenca del río Bio-Bío (IX Región, Chile). Bosque, 14(1): 45-54. [En línea], consultado el 02 de febrero de 2009. Disponible en: http://mingaonline.uach.cl/scielo.php?pid=S0717 -92001993000100006\&script=sci_arttext

Pizarro, R., Sangüesa, C., Flores, J.P., Martínez, E. 2005. Investigación e innovación tecnológica en zanjas de infiltración y canales de desviación, en el Secano Costero e Interior de las Regiones VI, VII y VIII de Chile. En: Lobo D. y D. Gabriels (Eds). Evaluación de Parámetros y Procesos hidrológicos en el Suelo. Documentos Técnicos en Hidrología del PHI, (UNESCO) 71: $119-124$.

Porta, J., Lopez, M., Roquero, C. 1999. Edafología para la agricultura y el medio ambiente. Madrid, España, Ediciones MundiPrensa.849 p.

Renard, K.G., Foster, G.R., Weesies, G.A., McCool, D.K., Yoder, D.C. 1996. Predicting soil erosion by water: a guide to conservation 
planning with the Revised Universal Soil Loss Equation (RUSLE). Agriculture Handbook 703. USDA-ARS, 384 pp.

Riquelme, J. 1994. Calibration of erosion productivity model EPICfor three soil tillage systems in the secano interior of Chile. $8^{\text {th }}$ ISCO Conference. New Delhi, India. 15 pp.

Santibáñez, F., Vargas, X., Alvarez, D., Caviedes, E., Azocar, P., Hamelin, P. 1998. Estudio propuesta de plan de accion sobre la desertificacion, IV Region, 170. Universidad de Chile, Santiago, Chile.

Shaeffer, D. 1980. A model evaluation methodology applicable to environmental assessment models. Ecol. Model. 8: 275-295.

Soto, G., 1999. Preliminary map of desertification in Chile - per community (In Spanish). Corporación Nacional Forestal, Santiago, Chile, $88 \mathrm{pp}$.

Tokugawa K., Vargas, R. 1996. Control de erosión y forestación en cuencas hidrográficas de la zona semiárida de Chile. Informe intermedio de control de erosión. Proyecto CONAF - JICA. Chile. 72 p.

USDA. 1993. Soil Survey Manual, Segunda Edición. United States Department of Agriculture,Washington, Estados Unidos. 437 p.

Valenzuela, B., Morales, L.S. 2004. Estimación del factor de erosividad de las precipitaciones en la Región de Coquimbo. XIV Simposio Chileno de Física, Antofagasta. Chile. 3p. [En línea], consultado el 20 de febrero de 2009. En: http://www.fisica.ucn.cl/sochifi/simposio2004/act a/contribuciones/AA-406.pdf
Vandekerckhove, B. 2006. Estimation of sediment transport in a watershed in an arid region of north Chile. MSc. Thesis. Ghent University, Belgium. 115 p.

Verbist, K., Robertson, A.W., Cornelis, W., Gabriels, D., 2010. Seasonal predictability of daily rainfall characteristics in central-northern Chile for dry-land management. J. Appl. Meteorol. Clim., 49(9), 1938-1955.

Verbist, K., Schiettecatte, W., Gabriels, D., 2003. Usability of rainfall simulation experiments to assess soil erosion under natural rainfall. In: Gabriels, D., Cornelis, W.M. (Eds.), International Symposium on 25 years of assessment of erosion, Ghent, Belgium, pp. 269-276.

Willmott, C., Wicks, D. 1980. An empirical method for the spatial interpolation of monthly precipitation within California. Phys. Geogr. 1: 59-73.

Wischmeier, W.H., Smith, D.D. 1978 Predicting soil erosion losses: A guide to conservation planning. USDA Agriculture Handbook 537. 58 p.

Wischmeyer, G., Foster, G. 1980. Guide for predicting sheet and rill erosion on forestland. USDA. Forest servicie. $40 \mathrm{p}$. 